\title{
Four New Species of Peruvian Gentianella (Gentianaceae)
}

\author{
James S. Pringle \\ Royal Botanical Gardens, P.O. Box 399, Hamilton, Ontario, Canada L8N 3H8. jpringle@rbg.ca
}

ABstract. Four new species of Gentianella Moench are described from Peru. Gentianella iberidea J. S. Pringle differs from G. graminea (Kunth) Fabris in its obtuse, non-arcuate leaves. Gentianella sagasteguii J. S. Pringle differs from similar species in its combination of linear-elliptic leaves, narrowly triangular calyx lobes, and lilac, widely campanulate to subrotate corollas with the lobes (1.1-) $1.7-2 \times$ as long as the tube. Gentianella smithii J. S. Pringle differs from $G$. paludicola (Gilg) J. S. Pringle and $G$. roseolilacina (Gilg) J. S. Pringle in its perennial habit and blue corollas. Gentianella uberula J. S. Pringle differs from $G$. sagasteguii in its wider leaves and less deeply lobed corollas.

Resumen. Se describen cuatro nuevas especies de Gentianella Moench del Perú. Gentianella iberidea J. S. Pringle se diferencia de $G$. graminea (Kunth) Fabris por las hojas obtusas no arqueadas. Gentianella sagasteguii J. S. Pringle se diferencia de las especies de hábito parecido por las hojas lineares, las lóbulos del cáliz angustamente triangulares y las corolas lilacinas de lóbulos de largo (1.1-)1.7-2× que del tubo. Gentianella smithii J. S. Pringle se diferencia de G. paludicola (Gilg) J. S. Pringle y G. roseolilacina (Gilg) J. S. Pringle por el hábito perenne y las corolas azules. Gentianella uberula J. S. Pringle se diferencia de G. sagasteguii por las hojas más anchos y las corolas lobulados menos profundamente.

\section{Key words: Gentianaceae, Gentianella, Peru.}

The mountains of northern Peru are the habitat of a number of recently discovered species of Gentianella Moench (Gentianaceae), four of which are described here. The descriptions in this paper are based on specimens at HAM and MO; the replicates at other herbaria were not seen in this study.

1. Gentianella iberidea J. S. Pringle, sp. nov. TYPE: Peru. Piura: Prov. Huancabamba, Jalca (San Antonio-Talaneo), 3200 m, A. Sagástegui A. \& J. Cabanillas S. 8614 (holotype, HAM; isotypes, HUT not seen, MO). Figure 1.

Herba perennis caespitosa aspectu inter Gentianellam gramineam (Kunth) Fabris et $G$. androsaceam J. S. Pringle intermedia, sed a $G$. graminea caulibus distaliter foliis abruptius dissitis et foliis plerumque obtusis non arcuatis basi vaginantibus, a $G$. androsacea caulibus plus numerosis et floribus paucioribus minoribusque differens.

Clump- or patch-forming perennial with many somewhat woody, decumbent stems elongating through substrate, branching, older portions producing many adventitious roots; vegetative and flowering stems present simultaneously; portion of vegetative stems with green leaves of current season $1.5-6 \mathrm{~cm}$, that of flowering stems $8-20 \mathrm{~cm}$, simple. Leaves of vegetative stems and proximal $1.5-7 \mathrm{~cm}$ of flowering stems crowded; middle and upper cauline leaves of flowering stems in 3 to 5 pairs, separated by 1.5$5.5 \mathrm{~cm}$; leaves nearly linear, slightly widened distally, 1-nerved, 10-25 × 1.2-2 mm; bases of proximal and midstem leaves connate-sheathing ca. $1 \mathrm{~mm}$ or less; apices mostly obtuse, those of uppermost leaves subacute. Flowers 3 to 7 in a reduced dichasium, usually 3 to 5 flowers in a terminal cluster, or 3 terminal flowers and 1 from each of a pair of axils less than $1 \mathrm{~cm}$ below; upper pedicels mostly $7-20 \mathrm{~mm}$, lower to $40 \mathrm{~mm}$, cyme thus being corymboid; occasionally 1 or 2 flowers at second node below summit on pedicels to $20 \mathrm{~mm}$, or some abortive. Calyx 8-11 mm; calyx lobes lanceolate-triangular, 4.5-7 $\times$ $1.2-2 \mathrm{~mm}$, acute; corolla funnelform-campanulate, $12-21 \mathrm{~mm}$, white with veins toward base of lobes outlined in violet, glabrous within; lobes spatulateobovate, $1.5-2 \times$ as long as tube, $1.5-2.5 \times$ as long as wide, rounded at apex.

Etymology. This new species is named for its resemblance to Iberis saxatilis $\mathrm{L}$. and narrow-leaved forms of I. sempervirens L. in general aspect, although upon the arrival of a paratype the specific epithet coincidentally became a wordplay on the name of Gustavo Iberico Vela, a co-collector of Sánchez V. et al. 10736.

Discussion. In gross morphology, Gentianella iberidea is intermediate between G. graminea (Kunth) Fabris of Amazonas and Cajamarca departments, Peru, and G. androsacea J. S. Pringle of southern Ecuador. It differs from $G$. graminea in its more abrupt transition from closely spaced near-basal leaves to widely separated middle and distal cauline leaves, scarcely to not at all arcuate leaves, connatesheathing bases of the proximal leaves, and obtuse to subacute rather than acute to acuminate leaf apices. It 

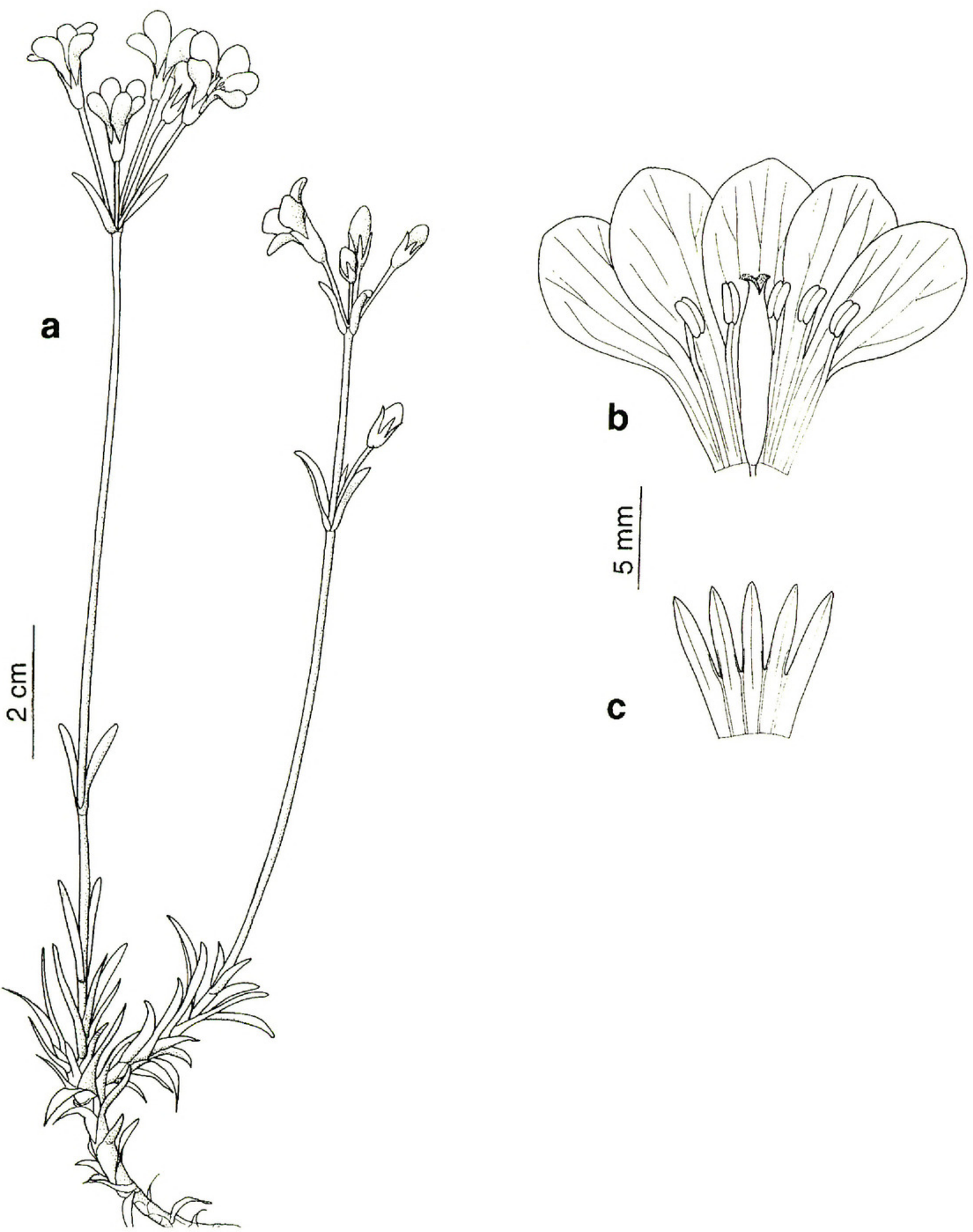

Figure 1. Gentianella iberidea J. S. Pringle. —a. Habil. — b. Corolla, stamens, and pistil. —c. Calyx. Drawn from the type, Sagástegui \& Cabanillas 8614 (HAM).

differs from $G$. androsacea in its greater number of stems per plant, forming loose clumps or small patches; narrower, l-nerved leaves; proximal cauline leaves that are not strictly crowded into basal rosettes; and stems in the vegetative stage that elongate to several centimeters rather than remaining as rosettes.
The maximum number of flowers per inflorescence is much fewer than in $G$. androsacea. These features also distinguish it from $G$. corymbosa (Kunth) Weaver \& Rüdenberg of Colombia. It differs from $G$. oreosilene (Gilg) J. S. Pringle, of Amazonas Department, in the same respects as from $G$. graminea and also in its 


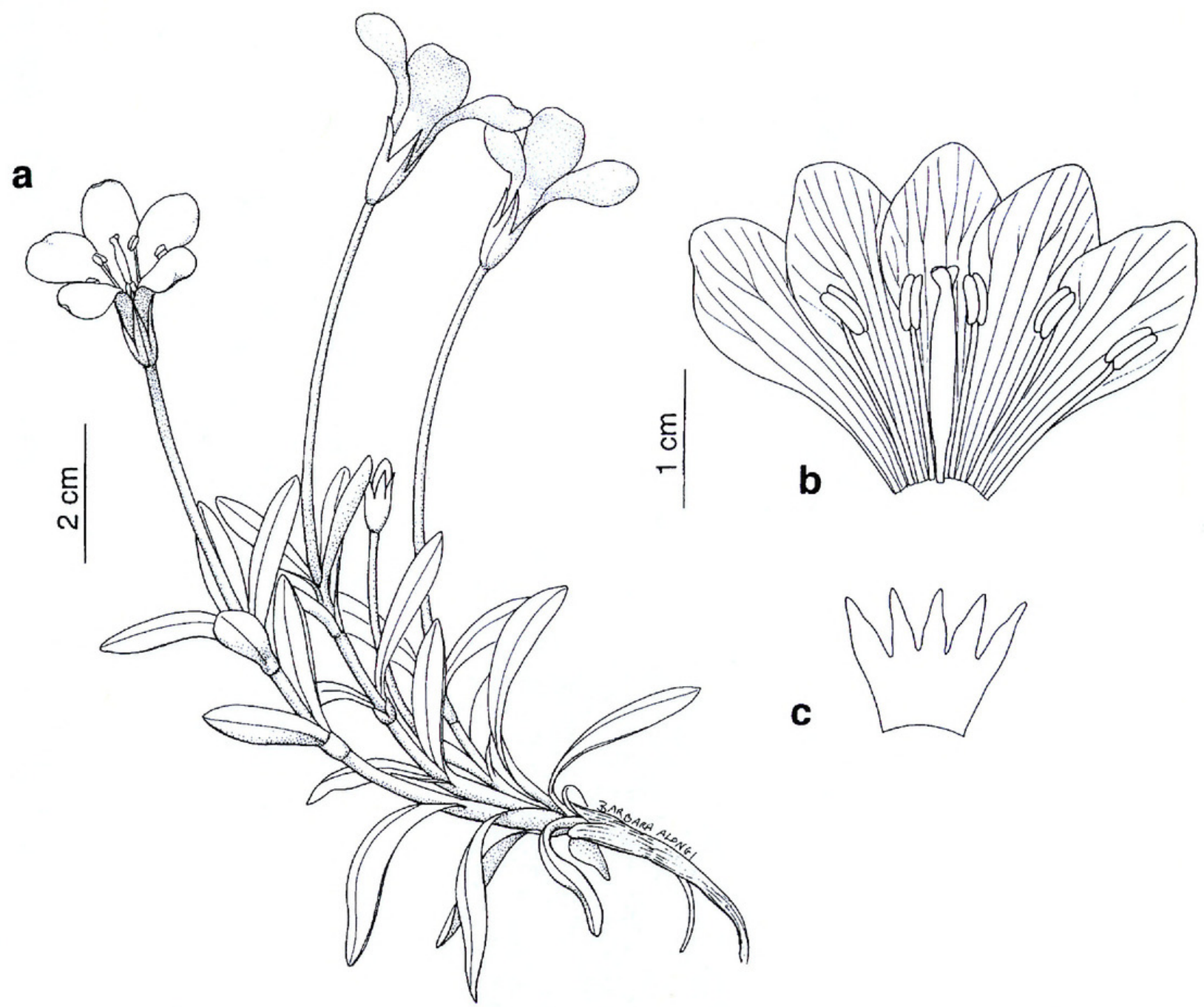

Figure 2. Gentianella sagasteguii J. S. Pringle. —a. Habit. - b. Corolla, stamens, and pistil. —c. Calyx. Drawn from the type, Sagástegui et al. 14000 (HAM).

corymboid or umbelloid rather than more elongate, racemoid inflorescences.

Paratypes. PERU. Cajamarea: Prov. Hualguyoc, $5 \mathrm{~km}$ de la carretera a Yanacanchilla Alta, desvio de la carretera a Hualgayoc (Area Las Lagunas), $6^{\circ} 52^{\prime} \mathrm{S}, 78^{\circ} 35^{\prime} \mathrm{W}, 3950 \mathrm{~m}, I$. Sánchez V. G. Iberico \& J. Salcedo A. 10736 (CPUN, F, HAM).

2. Gentianella sagasteguii J. S. Pringle, sp. nov. TYPE: Peru. Cajamarca: Prov. Contumazá, pozo Kuán, 3790 m, A. Sagástegui A., R. Ramírez, E. García \& S. Leiva 14000 (holotype, HAM; isotypes, F not seen, HUT not seen). Figure 2.

Herba perennis caespitosa foliis dense aggregatis et floribus solitariis, a speciebus similibus in Peruvia septentrionali foliis lineari-ellipticis, calycibus nervis prominentibus et lobulis anguste triangularibus vel oblongo-triangularibus et corollis lilacinis late infundibuliformi-campanulatis usque subrotatis lobulis quam tubo (1.1-)1.7-2plo longioribus distinguenda.

Caespitose perennial; vegetative stems to $4 \mathrm{~cm}$ present along with flowering stems; flowering stems \pm decumbent, simple, $1-4 \mathrm{~cm}$ long exclusive of peduncle. Leaves all closely spaced on vegetative stems, usually 1 or 2 pairs above those crowded near base on flowering stems. Leaves linear-elliptic, 1- or obscurely 3- or 5-nerved, 10-18 × 1-2 mm; lower leaves subacute, upper acute; bases connate-sheathing $2-$ $4 \mathrm{~mm}$ or uppermost pair with shorter sheaths; leaf margins smooth. Flowers solitary, erect; peduncles 2$5 \mathrm{~cm}$, purplish distally. Calyx 8-11 mm, midveins and commissural veins raised, outlined with purple suffusion; lobes narrowly triangular or oblong-triangular, 4$5.5 \times 1.8-2.2 \mathrm{~mm}$, acuminate; corolla widely funnelform-campanulate to subrotate, $16-24 \mathrm{~mm}$, pale to medium violet, darker on exterior toward outer edge of lobes; inner surface with a few trichomes $0.3-0.8 \mathrm{~mm}$ long above stamens, especially near sinuses; lobes spatulate-obovate, (1.1-)1.7-2× as long as tube, (1.4-) $1.8-2.2 \times$ as long as wide, rounded at apex.

Etymology. This species is named for its discoverer, Abundio Sagástegui Alva, in recognition of his 

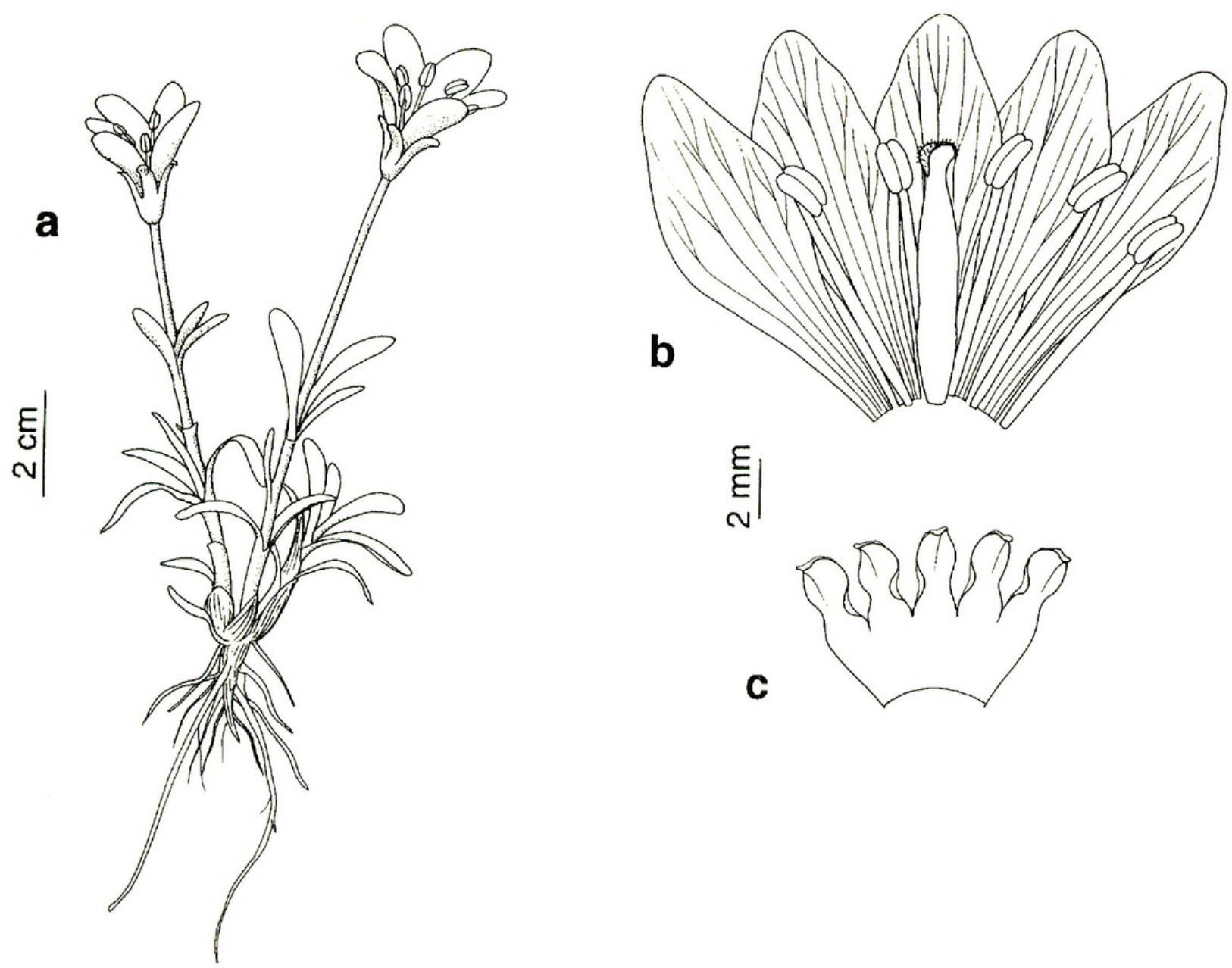

Figure 3. Gentianella smithii J. S. Pringle. — a. Habit. — b. Corolla, stamens, and pistil. —c. Calyx. Drawn from the type, Smith \& Torres 11774. (HAM).

contributions to the knowledge of the flora of northern Peru.

Discussion. The combination of narrow, nearly linear leaves and deeply lobed, violet corollas with widely spreading lobes distinguishes Gentianella sagasteguii from other solitary-flowered Gentianella species in northern Peru. The ridged calyx tube and lobes also contribute to its distinctness.

Paratypes. PERU. Cajamarea: Prov. Contumazá, alrededores del pozo Kuán, 3600-3800 m, A. Sagáslegui A., E. García, S. López \& J. Mostacero 10079 (HAM, HUT not seen, MO); Prov. Contumazá, jalca del pozo Kuán, 4000 m, A. Sagástegui A., E. Alvílez \& J. Mostacero 10785 (HAM, HUT not seen, MO); Prov. Cajabamba, Llamacorral (ruta a Luchubamba), $7^{\circ} 33.8^{\prime} \mathrm{S}, 78^{\circ} 01.3^{\prime} \mathrm{W}, 3750 \mathrm{~m}, 4$ Aug. 2002, A. Sagástegui A., M. Zapata \& J. Leal 16960 (F, HAM, HAO). La Libertad: Prov. Otuzco, arriba de la escuela de Purrupampa, 3490 m, S. Leiva \& P. Leiva 336 (F, HAM).

3. Gentianella smithii J. S. Pringle, sp. nov. TYPE: Peru. Ancash: Prov. Recuay, Huascarán Natl. Park, Río Pachacoto drainage at mineral springs near Carpa $\left(77^{\circ} 7^{\prime} \mathrm{W}, 9^{\circ} 53^{\prime} \mathrm{S}\right), 4200 \mathrm{~m}, \mathrm{D} . \quad \mathrm{N}$.
Smith \& M. Torres 11774 (holotype, HAM; isotype, MO). Figure 3.

Herba caespitosa Gentianellae paludicolae (Gilg) J. S. Pringle et $G$. roseolilacinae (Gilg) J. S. Pringle similis, sed ab eis habitu perenni et foliis apice obtusis, lobulis calycis oblongis vel interdum oblongo-oblanceolatis abrupte acutis et corollis lilacinis, etiam a $G$. paludicola plantis minoribus et a $G$. roseolilacina corollis profundius lobatis differens.

Caespitose perennial; older stems covered with remains of leaves of previous season; vegetative rosettes present along with flowering stems, the latter decumbent, currently leafy portion to $1.5 \mathrm{~cm}$ long below peduncle. Leaves of flowering stems in 1 to 3 pairs, crowded or separated by internodes less than $1 \mathrm{~cm}$ long. Leaves narrowly oblanceolate to narrowly obovate, to 7 -nerved but with only 1 or 3 nerves prominent, $6-18 \times 1.5-3.5 \mathrm{~mm}$, bases connatesheathing $2.5-4 \mathrm{~mm}$, sheaths often overlapping, apices obtuse; leaf margins smooth, not thickened. Flowers solitary; peduncle $15-30 \mathrm{~mm}$, \pm suffused with purple. Calyx $6.5-8 \mathrm{~mm}$; calyx lobes oblong or occasionally oblong-oblanceolate to narrowly ovate, $3.5-5 \times 1.5-2 \mathrm{~mm}$, abruptly acute, often carinate- 

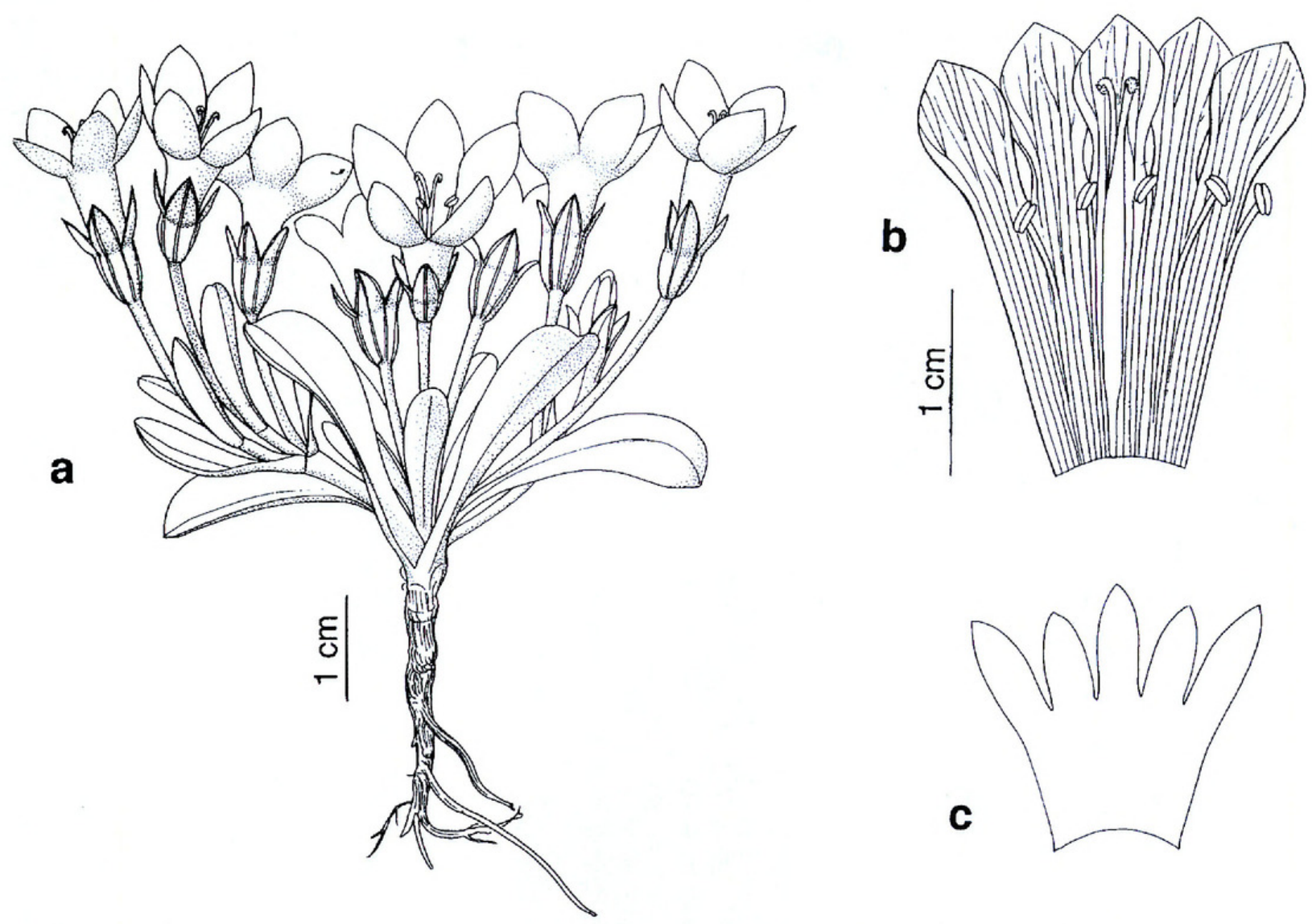

Figure 4. Gentianella uberula J. S. Pringle. —a. Habit. — b. Corolla, stamens, and pistil. —c. Calyx. Drawn from the type, Sagástegui et al. 12043 (HAM).

conduplicate and recurved toward apex, margins smooth; corolla widely funnelform-campanulate, 13$16 \mathrm{~mm}$, light violet-blue with yellowish green base, glabrous within; lobes elliptic-rhombic, $2.2-3 \times$ as long as tube, $2-2.4 \times$ as long as wide, subacute; anthers purple.

Etymology. This species is named in memory of its discoverer, David Nelson Smith (1945-1991), in recognition of his contributions to the floristic knowledge of Peru and Bolivia.

Discussion. Gentianella smithii is similar to $G$. paludicola, which also occurs in Ancash Department, Peru, but it does not seem possible to interpret it as constituting very small plants of that species. Gentianella smithii is obviously a caespitose perennial, whereas $G$. paludicola is evidently monocarpic; the leaves of $G$. smithii are rounded to obtuse at the apex, whereas those of $G$. paludicola are acute; the calyx lobes are of different shapes, those of G. smithii being oblong and abruptly acute, and those of $G$. paludicola being lanceolate and acuminate; and the corollas of $G$. smithii were described by Smith (in sched., type) as "purplish blue, yellowish green at base," whereas those of $G$. paludicola were described by Weberbauer (in Gilg, 1906: 42, translated) as "white, externally violet-nerved" above the yellowish throat. The type of
G. smithii was found in "boggy ground in bottom, soil very wet or saturated" (in sched.), so the lower stature and generally different aspect of these specimens cannot be attributed to a drier habitat than that of the type of $G$. paludicola.

Gentianella roseolilacina is another solitary-flowered species in Ancash Department, which was frequently encountered by Smith and his associates in Huascarán National Park. It differs from G. smithii in its apparently monocarpic habit; narrower, acuminate calyx lobes; light magenta or pinkish violet rather than violet-blue corollas; and corolla lobes scarcely longer than the tube. Gentianella cerrateae Fabris, also of Ancash Department, differs in its much smaller flowers with the corolla lobes distinctly shorter than the tube.

4. Gentianella uberula J. S. Pringle, sp. nov. TYPE: Peru. Cajamarca: Prov. Celendín, La Encañada, 3350 m, A. Sagástegui A., J. Mostacero \& S. Leiva 12043 (holotype, HAM; isotypes, HUT not seen, MO). Figure 4.

Herba perennis caespitosa a Gentianella sagasteguii J. S. Pringle foliis latioribus et corollis minus profunde lobatis distinguenda.

Caespitose perennial; tap root and caudex stout (4$8 \mathrm{~mm}$ diam. near summit), caudex covered with 
remains of old leaf bases; stems many, decumbent, to $3.5 \mathrm{~cm}$ exclusive of terminal peduncle; rosettes and/or vegetative stems to $3 \mathrm{~cm}$ present along with flowering stem; stems mostly simple, with basal leaves only; longest stems with 1 to 3 pairs of cauline leaves, these sometimes in false whorls (one pair immediately above another), sometimes with paired branches each with 1 pair of leaves; flowering stems \pm decumbent, simple, $0.5-3.5 \mathrm{~cm}$ long exclusive of peduncle. Leaves 3- to 7 -nerved but usually only midrib prominent, 9-20 $\times$ $2-5 \mathrm{~mm}$; rosette, basal, and lower cauline leaves linear-oblanceolate or with a \pm petiolar base gradually expanding into a spatulate to ellipticoblanceolate, distal portion, bases connate-sheathing to $4 \mathrm{~mm}$, apices obtuse to subacute; transitional to oblanceolate distal leaves (if present) without petiolar base, bases scarcely or not sheathing, apices acute; pale leaf margins ca. $0.05-0.1 \mathrm{~mm}$ wide, sharply differentiated, smooth or minutely undulate. Flowers solitary; peduncles 4-70 mm, purple-tinged. Calyx 7$18 \mathrm{~mm}$, \pm suffused with purple, midveins and commissural veins raised; calyx lobes oblong-lanceolate to narrowly triangular, 3-12 mm long, 1-3.5 mm wide at base, varying in width on same calyx, obtuse to acute, margins smooth or minutely undulate; corolla funnelform-campanulate, 14-35 mm, lilac to purple (see notes below), pale yellow toward base, glabrous within; corolla lobes spatulate-elliptic to spatulateobovate, (0.6-)0.8-1.2× as long as tube, $1.5-2 \times$ as long as wide, obtuse to abruptly acute; anthers pale yellow.

Etymology. The specific epithet is derived from the Latin word meaning "fruitful," with a diminutive suffix, referring to the abundance of proportionately large, showy flowers produced by small plants.

Discussion. Gentianella uberula is similar to $G$. sagasteguii, but differs in its obluse to acute rather than acuminate calyx lobes and in its much less deeply divided corolla blotched at the throat. From $G$. smithii it differs in its less deeply lobed corolla with proportionately wider lobes.

From the appearance of the herbarium specimens, the corollas of the holotype and those of the paratype Sagástegui A. \& Zapata C. 16472, in both cases described by Sagástegui (in sched.) as "moradas," appear to have been rather deep purple. The predominant corolla color of some of the paratypes, described (in sched.) as "lilas" or "liladas," appears to have been paler, and that of another paratype, described as "violáceas," appears to have been similar or slightly darker. In some specimens, the corollas appear especially boldly patterned. Above the yellow base are five deeply colored blotches, above which a pale zone is transitional to the lilac or violet of the greater part of the lobes. Similar corolla blotches occur in the Bolivian Gentianella bockii (Gilg) T. N. Ho \& S. W. Liu and G. neomandonii (R. C. Foster) T. N. Ho \& S. W. Liu, but G. uberula differs from these geographically distant species in its less deeply lobed calyx and corolla and from G. neomandonii, especially, in its narrower leaves.

Paralypes. PERU. Cajamarca: Prov. Cajamarca, Jalca Kumulca (Km 54 ruta Cajamarca-Celendín), 3700 m, A. Sagástegui A., J. Luteyn \& D. S. Sylva 15779 (HAM, HAO, NY). La Libertad: Prov. Sánchez Carrión, señal Huaylillas, $78^{\circ} 02^{\prime} \mathrm{W}, 7^{\circ} 53^{\prime} \mathrm{S}, 4300 \mathrm{~m}$, D. N. Smith 2254 (HAM, MO); Prov. Sánchez Carrión, alrededores de laguna Cushuro (pie del Nevado Huaylillas), $7^{\circ} 54^{\prime} \mathrm{S}, 78^{\circ} 00^{\prime} \mathrm{W}$, jalca, $4078 \mathrm{~m}, A$. Sagástegui A. \& M. E. Zapata C. 16472 (F, HAM, HAO); Prov. Santiago de Chuco, Jalca de Quesquenda, $7^{\circ} 55.3^{\prime} \mathrm{S}$, $78^{\circ} 10.2^{\prime}$ W, $3960 \mathrm{~m}$, A. Sagástegui A. \& M. E. Zapata C. 16578 (F, HAM, HAO); Prov. Pataz, Alto Togana, Tayahamba-Huancaspata, $4000 \mathrm{~m}$, A. López M. \& A. Sagástegui A. 8199 (HAM, HUT not seen, MO); Prov. Santiago de Chuco, Pampas de la Julia, $7^{\circ} 55.5^{\prime} \mathrm{S}, 78^{\circ} 18^{\prime} \mathrm{W}, 4060 \mathrm{~m}, \mathrm{~A}$. Sagástegui A., M. Zapata \& J. Leal 16942 (F, HAM, HAO); Prov. Pataz, Laguna Cujibamba (Huaylillas), 809.6'S, $77^{\circ} 18.7^{\prime} \mathrm{W}, 3900 \mathrm{~m}$, A. Sagástegui A. \& M. Zapala 17018 (F, HAM, HAO).

Acknowledgments. Some of the specimens cited here were collected by A. Sagástegui Alva et al. under the auspices of the Flora of Peru project, a collaborative effort of the Missouri Botanical Garden, the Field Museum of Natural History, the Universidad Nacional Mayor de San Marcos, and the Universidad Nacional de Amazonía Peruana, with fieldwork supported by the National Science Foundation and the United States Agency for International Development (USAID). I am grateful to the herbarium and library staff of the Missouri Botanical Garden for access to specimens and publications. I am also grateful for the illustrations by Barbara Alongi. This paper is Contribution No. 175 from the Royal Botanical Gardens, Hamilton, Ontario, Canada.

\section{Literature Cited}

Gilg, E. 1906. Beiträge zur Kenntnis der Gentianaceae. Repert. Spec. Nov. Regni Veg. 2: 3-56. 


\section{$2 \mathrm{BHL}$ Biodiversity Heritage Library}

Pringle, James S. 2008. "Four new species of Peruvian Gentianella (Gentianaceae)." Novon a journal of botanical nomenclature from the Missouri Botanical Garden 18, 511-516.

View This Item Online: https://www.biodiversitylibrary.org/item/55381

Permalink: https://www.biodiversitylibrary.org/partpdf/58017

\section{Holding Institution}

Missouri Botanical Garden, Peter H. Raven Library

\section{Sponsored by}

Missouri Botanical Garden

\section{Copyright \& Reuse}

Copyright Status: In copyright. Digitized with the permission of the rights holder.

License: http://creativecommons.org/licenses/by-nc-sa/3.0/

Rights: https://biodiversitylibrary.org/permissions

This document was created from content at the Biodiversity Heritage Library, the world's largest open access digital library for biodiversity literature and archives. Visit BHL at https://www.biodiversitylibrary.org. 